\title{
Algal composition and abundance in the neuston surface micro layer from a lake and pond in Virginia (U.S.A.)
}

\author{
Lubomira BURCHARDT and Harold G. MARSHALL ${ }^{1)}$ \\ Department of Hydrobiology, Adam Mickiewicz University, Poznan, Poland \\ ${ }^{1)}$ Department of Biological Sciences, Old Dominion University, Norfolk, Virginia, U.S.A.
}

\begin{abstract}
A comparative study was conducted that characterized the algae within the neuston, ca $2 \mathrm{~mm}$ below the surface, and the algae in the water column from two freshwater habitats. There were significant differences in total algal abundance and the abundance of diatoms, cyanoprokaryotes, and chlorophytes between the neuston and water column algae of these two regions during each season and at both sites. The pond neuston was dominated by chlorophytes, with total algal abundance ranging seasonally from 0.6 to 59.6

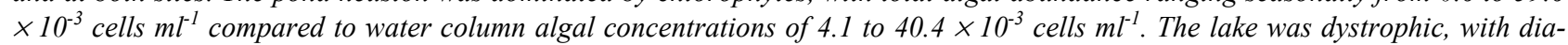

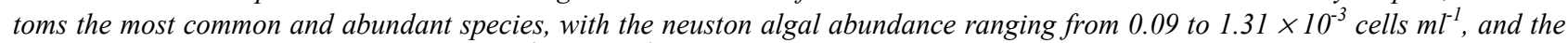

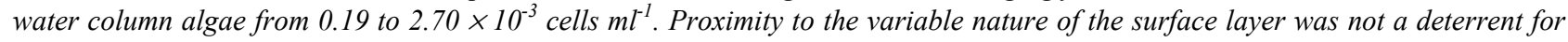
neuston algal development, which frequently reached bloom status and contained a diverse assemblage of taxa.
\end{abstract}

Key words: neuston, freshwater, algae, phytoplankton

\section{INTRODUCTION}

The neuston is composed of organisms associated with the surface film region of freshwater and oceanic habitats (Naumann 1917; Welch 1935; Geitler 1942; Zeitsev 1971). Due to its location, this communitiy has been identified as having a significant role in the dynamics of various ecosystem relationships of freshwater habitats and the world's oceans (Zeitsev 1971; Gladyshev 1986; Hardy 1997). The neuston has been divided into two populatons by Welch (1935) and Geitler (1942) as the epineuston (supraneuston) composed of organisms living on the surface film of the air-water interface, and the hyponeuston (infraneuston), which is characterized as organisms either attached to, or are directly below the surface film. The terms first suggested by Welch (1935) as the supra- and infraneuston are found less frequently in the literature to the more commonly accepted descriptive terms of epi- and hyponeuston proposed by Geitler (1942). The neuston region is a unique habitat that includes the exchange region where air/water molecular passage occurs, where light intensity of the water column is greatest, and where a variety of hydrophilic substances and air-borne pollutants accumulate (Hardy 1997). The neuston often contains a diverse assemblage of algae, bacteria, plus various life stages of zooplankton (e.g. eggs, larvae) and fish (Welch 1935; Geitler 1942; Zaitsev 1971; Gladyshev 1986). Distinct changes occur daily in the passage of light through this region, plus differences in its chemical composition and biota, compared to conditions and populations in the lower depths of the water column (Geitler 1942; Zeitsev 1971; Hardy 1997). The width of the neuston region varies among both freshwater and marine habitats, being influenced by season and the calmness or stability of the upper water column. In marine waters, Zaitsev (1971) considers the hyponeuston depth as from 0 to $5 \mathrm{~cm}$ below the water surface. In this report, the neuston algae studied are defined as those included in water $c a 2 \mathrm{~mm}$ of depth below the surface. These algae may be similar, different than, but not exclusive of taxa within the water column. The common methods for sampling neuston algae include using surfaces that would retain these taxa for analysis (Harvey 1966; Parker \& Barsom 1970; Harvey \& Burzell 1972; Maki \& Remsen 1983; Garrett \& Duce 1980; Estep et al. 1985). Glass plates, filter paper, microscope slides, teflon, screens, etc. may be placed on the water parallel to its surface to collect neuston generally to several $\mathrm{mm}$ of depth, or solid adsorbers (e.g. glass) may be inserted vertically into the water and slowly withdrawn to collect the surface film organisms. Another device is a rotating drum that skims off and collects the neuston surface layer (Harvey 1966; Münster et al. 1998).

Neuston collections were made in a shallow pond located in Norfolk, Virginia, with a 0.23 ha surface area and depth of ca $1.0 \mathrm{~m}$, and at Lake Drummond, a dystrophic lake in Chesapeake, Virginia, located within the Great Dismal Swamp Wildlife Refuge. The lake has a surface area of 7,750 ha, and a maximum depth of $2 \mathrm{~m}$ (Poore \& Marshall, 1972). The objectives of this study were to characterize and determine any differences in the abundance and composition of the sub-surface neuston algae to the water column algae in two very diverse freshwater habitats. 


\section{METHODS}

Surface water was collected using a hand-held glassplate $(30 \times 30 \mathrm{~cm})$. Initially, the neuston was collected by placing the glass plate on the water surface (without going below the surface), then withdrawing the glass, and collecting the water adhering to the glass using a wiper blade. In a second method, the glass was inserted vertically into the water. By slowly withdrawing the glass, a surface film of water adhered to the glass and was similarly wiped from the glass and collected. In each case, water adhering to the glass was measured as approximately $2 \mathrm{~mm}$ in thickness. Both methods gave similar results, but the first method proved more practical and efficient in the shallow regions of the pond, and was subsequently used at both sites.

Water adhering to the glass plate was collected in a container using a wiper blade. Repeated collections were made over different undisturbed water sites $(n=10)$. A total of $125 \mathrm{ml}$ was collected during each sampling date. Sub-surface water samples $(125 \mathrm{ml})$ were also taken at $c a 40 \mathrm{~cm}$ of depth. Each sample was preserved with Lugol's solution, and passed through a series of settling and siphoning procedures to produce a $40 \mathrm{ml}$ concentrate. Sub-samples from these concentrates were examined with light microscopy using an Utermöhl protocol and a Zeiss inverted microscope (at $315 \times$, $500 \times$ ) to determine species identification and abundance. Additional scanning electron microscopy (SEM) was used to assist in these identifications. Samples were taken ca mid-day, at the pond in August 2001, January, March, July, and November 2002, and at Lake Drummond in February, March, July, and November 2002.

In reporting algal abundance, four major categories were established: these were diatoms, cyanoprokaryotes (cyanobacteria), chlorophytes, and an others category. The others group was composed of taxa that were generally in low concentrations throughout the study (e.g. chrysophytes, cryptomonads, dinoflagellates).

\section{RESULTS}

Pond neuston concentrations were 16.5, 26.9, 59.6, 1.6 , and $0.62 \times 10^{-3}$ cells $\mathrm{ml}^{-1}$ for August, January, March, July, and November (Fig. 1). Water column algal concentrations for these months were 25.7, 19.4, $40.4,8.7$, and $4.1 \times 10^{-3}$ cells ml $^{-1}$. Both the pond neuston and water column contained a diverse, but similar algal representation in both regions (53 taxa). Dominant species included the chlorophytes Pediastrum duplex Meyen, P. simplex Meyen, Franceia ovalis (Francé) Lemm., Scenedesmus quadricauda (Turp.) Brébisson sensu Chodat, and Staurastrum paradoxum Meyen, plus the cyanoprokaryote Aphanizomenon flos-aquae (L.) Ralfs. The major diatom was Nitzschia acicularis W. Smith, and several other pennate diatoms that were most abundant in the surface micro layer during winter/spring. Chi-square analysis indicated significant dif- ferences $(p=0.001)$ in abundance occurred throughout each sampling date for the total algae composite, and for the total abundance for diatoms, chlorophytes, cyanoprokaryotes, and the others category, in comparing their concentrations in the neuston and water column. Collectively, there were higher algal concentrations in the neuston occurring during January, March, and November, and less in July and August (Fig. 1). Although not abundant, the phytoflagellate components (in the others category) were in higher monthly cell concentrations in the neuston, with the exception of November.

Lake Drummond neuston was less abundant and diverse (26 taxa) than the pond neuston with total algal concentrations of $1.31,0.55,0.09$, and $0.18 \times 10^{-3}$ cells $\mathrm{ml}^{-1}$ for February, March, July, and November; with water column algal concentrations of $2.7,0.3,0.19$, and $0.35 \times 10^{-3}$ cells ml $^{-1}$ for these months (Fig. 2). The lake $\mathrm{pH}$ ranged from 3.9 (July) to 4.9 (March), compared to the pond $\mathrm{pH}$, which ranged from 6.5 (November) to 7.2 (March). The diatoms were the most abundant category, followed by the chlorophytes, cyanoprokaryotes, and the others category. The dominant taxon in the neuston and water column of Lake Drummond was the diatom Asterionella ralfsii W. Smith. Other common species included the chlorophytes Scenedesmus helveticus Chodat, S. longispinum Chodat, Coelastrum reticulatum (Dang.) Senn, and Microthamnion strictissimum Rabenh., plus the diatoms Aulacoseira herzogii (Lemm.) Hickel Håkansson, A. granulata (Ehr.) Simonsen, and Eunotia monodon Ehr. Similar species were present throughout the water column. However, there were significant $(p=0.001)$ differences between concentrations of the total algae, diatoms, chlorophytes, and the others category in the neuston and water column on each sampling date. Similar significant differences in abundance occurred with the cyanoprokaryotes on three of the four sampling dates. The exception was July, when no cyanoprokaryotes were present in the samples. In comparison, the neuston had higher total cell concentrations than the water column only during March, with the water column having in general greater representation than the neuston of phytoflagellates (e.g. cryptomonads).

\section{DISCUSSION}

The neuston layer of ponds and lakes is considered unique compared to the deeper regions of the water column due to its proximity to the air-water interface and exposure to different water quality (e.g. levels of oxygen, nutrients, pollutants) and physical (e.g. degree of mixing, temperature, light intensity and composition) conditions (Gladyshev 1986). The neuston flora from both the pond and Lake Drummond contained a diverse representation of algae that was similar to taxa in their respective water columns. No unique floral assemblage was noted in the seasonal neuston samples. However, seasonal differences in abundance and dominant flora occurred in the neuston at each site, with the pond 


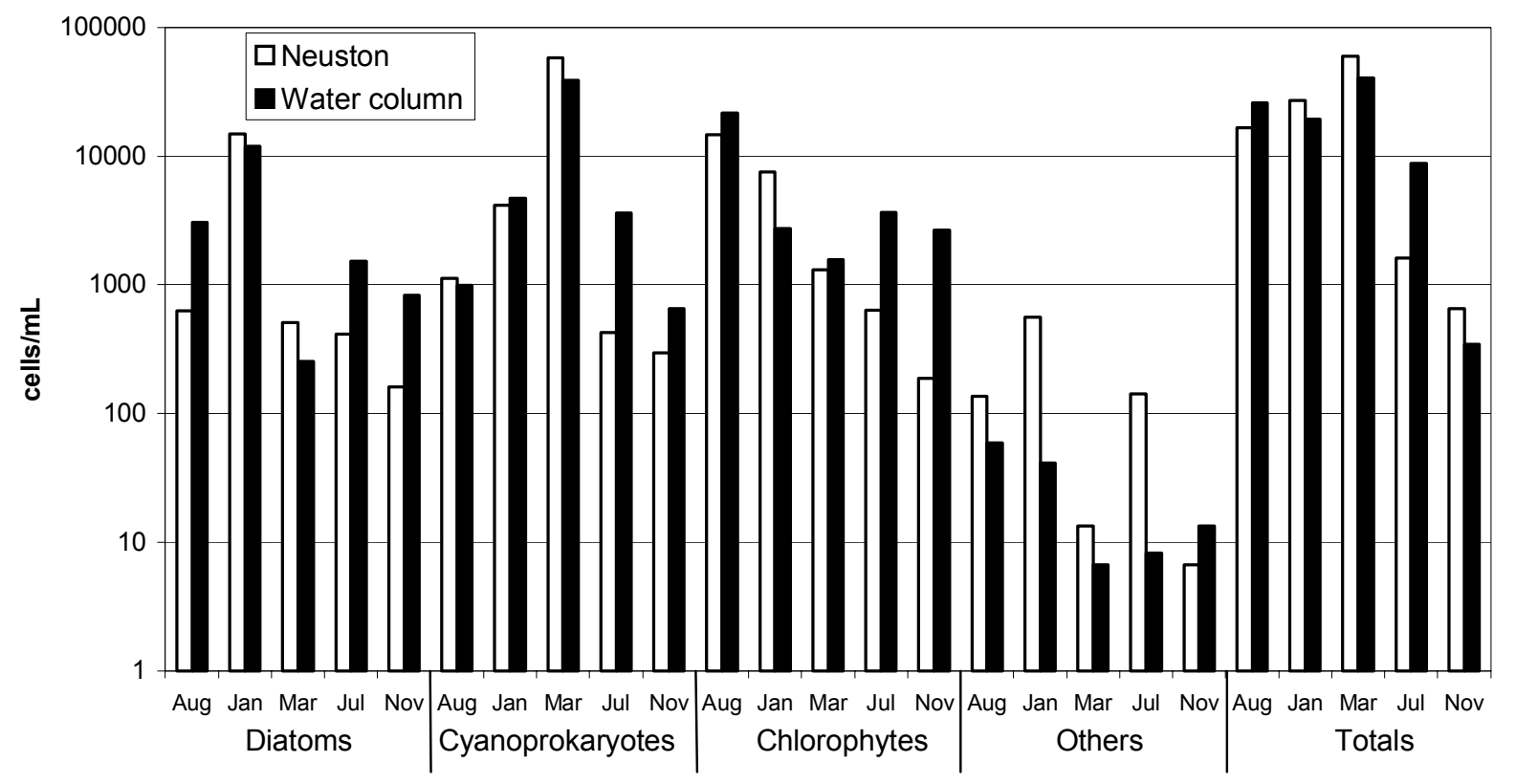

Fig. 1. Cell concentrations within the sub-surface neuston and water column in the pond August 2001, January, March, July and November 2002 .

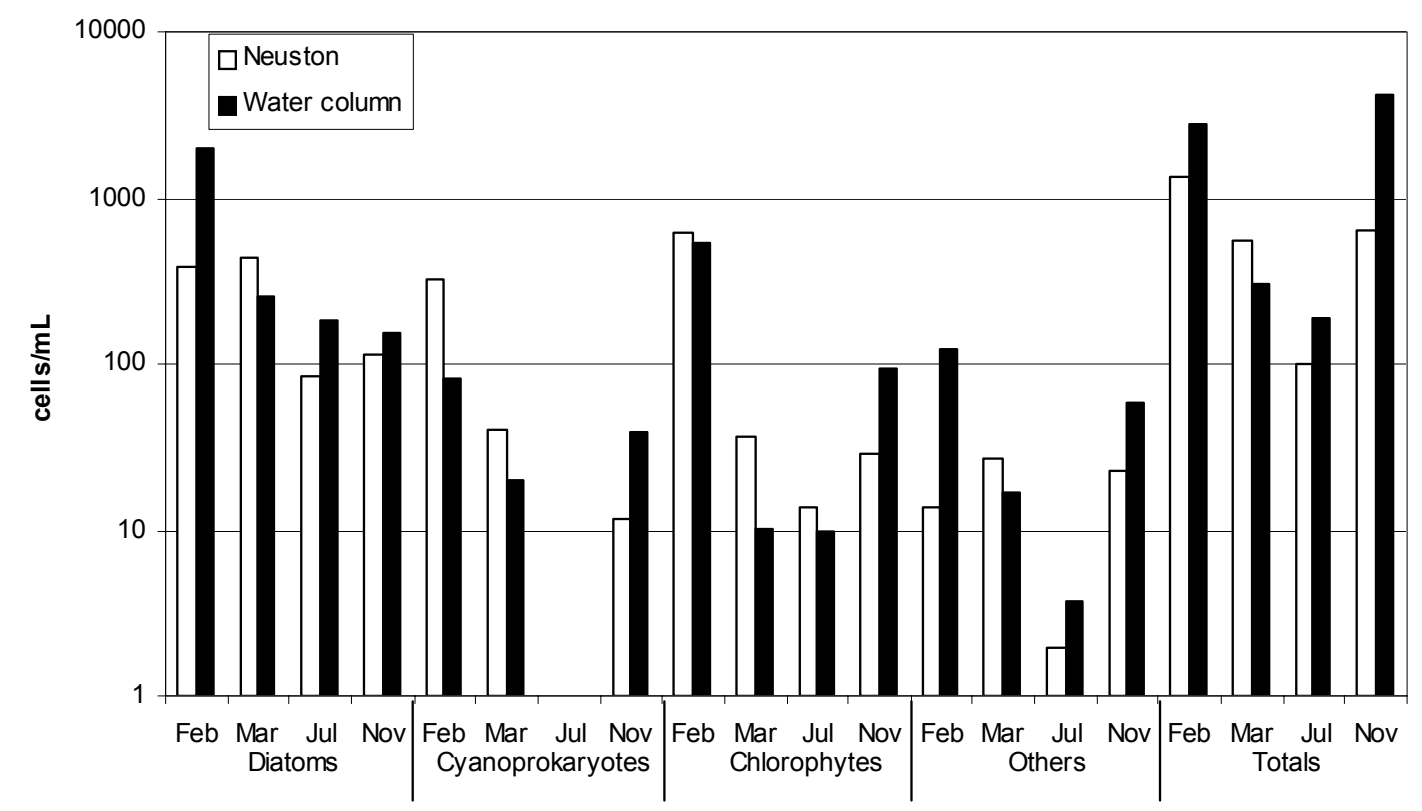

Fig. 2. Cell concentrations within the sub-surface neuston and water column in Lake Drummond February, March, July and November 2002.

neuston and pond water column algae having greater abundance and diversity compared to the dystrophic Lake Drummond. Münster et al. (1998) also noted differences in the surface microlayer of Evo lakes in Finland, where lower chlorophyll concentrations were found in the more acidic lake. Other factors influencing the neuston development at the two sites may include differences in the atmospheric products introduced to the neuston, the degree and frequency of vertical mixing of the entire water column, nutrient availability, and al- gal predators within these habitats. The pond is located in the center of Norfolk, subject to intermittent urban runoff, whereas, the lake is in the center of a national park and surrounded by woodlands. Since both of these habitats are shallow and exposed to prevailing winds, it is likely that mixing of these waters in common and has contributed to the similar representation of the algae in the water column and neuston.

The dominant phytoplankton in the pond were a variety of bloom producing chlorophytes (e.g. Pediastrum 
spp., Scenedesmus spp.), and in Lake Drummond, the diatoms predominated, with Asterionella ralfsii most abundant, along with other common diatoms (e.g. Aulacoseira spp.). Generally, not common at either site were cryptophytes, euglenophytes, chrysophytes, and dinoflagellates. An exception to this pattern, were high concentrations of cryptophytes during November in Lake Drummond, when Cryptomonas erosa exceeded $57.7 \times 10^{-3}$ cells $^{-1}$. The absence of greater phytoflagellate representation is possibly a sampling phenomenon that when collections were made, their concentrations were not abundant. This would be especially significant during the summer months, so that additional sampling at this time and throughout the year may indicate greater representation of these groups. Another explanation would be the environmental conditions were not suitable for their increased development. For instance, the availability of high concentrations of nutrients required by euglenophyta may be lacking at these sites, or stress conditions suppressing phytoflagellate development may be associated with the acidic conditions in Lake Drummond (Starmach 1983, Münster et al. (1998).

The neuston component examined here was located in the region directly below the surface film and may also be classified as hyponeuston (Welch 1935; Geitler 1942; Zeitsev 1971). These are cells not attached to the surface film, but are cells that inhabit the extreme upper range of the water column that is directly below the surface film. They can tolerate a different range of environmental conditions than those present in the water column, and are exposed to many of the more dynamic and extreme conditions associated with the air/water interface. This neuston component contained an abundant and diverse flora, showing significant seasonal differences in algal abundance to the water column phytoplankton. Bloom concentrations of the neuston taxa were at times in greater abundance compared to algae in the water column, indicating proximity to the surface layer was not a deterrent to the development of these dominant taxa. Although, the seasonal neuston abundance and composition in the two habitats differed in this study, the neuston component represented a diverse, and at times a very productive, community of cells at the extreme upper limits of the water column.

Received: January 2003

Accepted: June 2003

\section{REFERENCES}

Estep, K., J. Maki, S. Danos \& C. Remsen. 1985. The retrieval of material from the surface microlayer with screen and plate samplers and its implications for partitioning of material within the microlayer. Freshwat. Biol., 15: 15-19.

Garrett, W.D. \& R.A. Duce. 1980. Surface microlayer samplers. In: F. Dobson, L. Hasse, R. Davis (Eds), Air-Sea Interaction. Plenum, New York: 471-490.

Geitler, L. 1942. Zur Kenntnis der Bewohner des Oberflächenhäutchens einheimischer Gewässer. In: Biologia Generalis, Archiv. Für die Allegemeinen Fragen der Lebensforschung, Springer-Verlag, Wien: 450-475.

Gladyshev, M.I. 1986. Neuston of inland waters (A review). Hydrobiol. J., 22(5): 1-7.

Hardy, J.T. 1997. Biological effects of chemicals in the seasurface microlayer. In: P. Liss, R. Duce (Eds), The Sea Surface And Global Change. Cambridge University Press, N.Y.: 339-370.

Harvey, G.W. 1966. Microlayer collection from the sea surface: a new method and initial results. Limnol. Oceanogr., 11: 608-613.

Harvey, G.W. \& L.A. Burzell. 1972. A simple microlayer method for small samples. Limnol. Oceanogr., 17: 156157.

Maki, J. \& C. Remsen. 1983. A membrane adsorption-SEM technique for observing neuston organisms. Microb. Ecol., 9: 177-183.

Münster, U., E. Heikkinen \& J. Knulst. 1998. Nutrient composition, microbial biomass and activity at the air-water interface of small boreal forest lakes. Hydrobiologia. 363: 261-270.

Nauman, E. 1917. Beiträge zur Kenntnis der Teichnannoplanktons. II. Über das Neuston des Süsswassers, Biol. Zentralbl., 37(2): 98-106.

Parker, B. \& G. Barsom. 1970. Biological and chemical significance of surface microlayers in aquatic ecosystems. BioScience, 20: 87-93.

Poore, W.H. \& H.G. Marshall. 1972. Lake Drummond of the Dismal Swamp: I. Phytoplankton Composition. Virginia J. Science, 23(2): 72-76.

Starmach, K. 1983. Euglenophyta-Eugleniny. Flora Stodkowodna Polski. PAN. Instytut Botaniki. T.3. PWN. Kraków: 563 pp.

Welch, P.S. 1935. Limnology. McGraw-Hill Book Co., New York: $522 \mathrm{pp}$.

Zaitsev, Y.P. 1971. Marine Neustonology (translated from Russian). National Marine Fisheries Service, NOAA, and NSF. National Technical Information Service, Springfield, Virginia: 207 pp.

Zaitsev, Y.P. 1997. Neuston of seas and ocean. . In: P. Liss, R. Duce (Eds), The Sea Surface And Global Change. Cambridge University Press, N.Y.: 371-382. 